\title{
Az adat és a kormányzás jelentősége az okos város stratégiai alapú értékteremtési folyamatában - Magyar nagyvárosok összehasonlítása egy szintetizáló ökoszisztéma modell keretében
}

\section{The relevance of data and governance in the context of strategy- based value creation of smart cities - A comparitive study of Hungarian cities within the framework of a synthesizing ecosystem model}

\section{GYIMESI ÁRON, SOMLYÓDYNÉ PFEIL EDIT}

GYIMESI Áron: doktorandusz, Széchenyi István Egyetem, Regionális- és Gazdaságtudományi Doktori Iskola; 9026 Győr, Egyetem tér 1.; gyimesi.aron@yahoo.com; https://orcid.org/0000-0003-2873-6645

SOMLYÓDYNÉ PFEIL Edit: egyetemi tanár, Széchenyi István Egyetem, Kautz Gyula Gazdaságtudományi Kar; 9026 Győr, Egyetem tér 1.; somlyody@sze.hu; https://orcid.org/0000-0003-3372-4083

KULCSSZAVAK: okos város; e-government; városfejlesztési stratégia; adat; modell; okos kormányzás; szemantikai elemzés

ABSZTRAKT: Álláspontunk szerint az okos város az embert helyezi a középpontba, a technológia csupán a lehetőséget biztosítja arra, hogy a városok élhetőbbek, innovatívabbak legyenek, hatékonyabban müködjenek, és jobban megállják a helyüket a polgárokért vívott versenyben. A városok digitális átalakulása azonban tudatos stratégia mentén, a kijelölt prioritások betartásával, kizárólag akkurátus megvalósítással lehet sikeres. Tanulmányunkban sorra vesszük az okos várossá válás tekintetében meghatározó tényezőket. Elemezzük az okos várossá válás lehetséges fókuszpontjait, illetve megrajzoljuk azokat az összefüggéseket, amelyek valóban komplex kihívássá teszik az átalakulás folyamatát. Értékeljük a mért adat kiemelt helyét az okosváros-koncepcióban, és azonosítjuk az e-government fogalmát, valamint az okos kormányzás városvezetési módszertanát, mint az okos várossá válás értékteremtő irányítási metódusát. Úgy véljük, hogy ez a két tényező kiemelt fontosságú: ezek tartják fent a kapcsolatot az okos város megannyi koncepcionális alkotóeleme között, amelyeket egy, a céljai szerint szintetizáló, az elméleti és a pragmatikus okos város stratégiai modelleket egyesítő új ökoszisztéma modell keretei között jelenítünk meg. A modell alapgondolata szerint az okos várost egyfajta platformként képzeljük el, amelynek dinamikusan áramoltatnia kell az információkat és a feladatokat, átlépve a város hagyományos ágazatai között; egyszerre kielégítve a speciális ügykezelési szempontokat és a komplexebb kormányzásra vonatkozó igényeket. A modell integrálja, dinamizálja és fejlődésre sarkallja az okos város külső és belső szereplőit, strukturális és koncepcionális elemeit, valamint operatív testületeit és technológiai megoldásait.

A modellt egy olyan kutatás eredményeként jelenítjük meg, amely során öt magyarországi nagyváros okos város stratégiai dokumentumainak szemantikai elemzését valósítottuk meg. A stratégiai dokumentumok elemzése során elsődlegesen arra a kérdésre kerestük a választ, vajon a szakirodalom által rendszerezett okosváros-jellemzők,

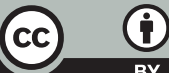


struktúrák megjelennek-e ezekben a dokumentumokban. Kerestük továbbá az elméleti munkákban dominánsan megjelenő ágazati megközelítéssel szakító modellünk visszaigazolását. A tanulmányunk törekvése, hogy egyensúlyt találjon az okosváros-paradigma komplex rendszerében, miközben rávilágít azokra a dinamikus elemi és absztrakt tényezőkre, amelyek annak motorjául szolgálnak.

Áron GYIMESI: PhD student, Doctoral School of Regional- and Business Administration Sciences, Széchenyi István University; Egyetem tér 1., H-9026 Győr, Hungary; gyimesi.aron@yahoo.com; https://orcid.org/0000-0003-2873-6645

Edit SOMLYÓDYNÉ PFEIL: professor, Kautz Gyula Faculty of Economics, Széchenyi István University; Egyetem tér 1., H-9026 Györ, Hungary; somlyody@sze.hu; https://orcid.org/0000-00033372-4083

KEYWORDS: smart city; government; urban development strategy; data; model; smart city; e-government; semantic analysis

ABSTRACT: The Smart City paradigm focuses on people, while technology serves as means for cities to become more liveable, innovative, effective. In this view technology is about to support cities in their competition to satisfy citizens' needs. The digital transformation of cities must be managed by detailed strategies along a set of priorities implemented accurately concentrating all the efforts towards a set of solutions that give answers to the digital challenges of cities. The first part of the paper discusses the most important elements of the digital transformation of smart cities, including the definition of the concept of smart city transition and factors that make transformation itself a real complex challenge. We underline and evaluate the role of data and also identify the governance/e-governance as a possible and effective public management methodology for smart city value creation. These two dynamic elements in abstraction operate the smart city as a system and provide connections among the countless conceptional items of future cities. Based on this idea a new synthesizing smart city model is introduced in the second part of the study, designed through iteration and semantic analysis. This model combines ideas of various theoretical models that are mainly based on city governing domains (i.e. city services, asset management, waste management, taxation services) and IT focused pragmatic models. Smart City is projected by us as a kind of platform that continuously maintains the flow of information and tasks delegated across the directorates of the city. The model integrates internal-, external actors, structural and conceptual elements, operative plenums and technologic solutions developed for the smart city. The model also shows that strategic level processes can take place next to IT solutions - symbolizing Smart City as a system operable. Smart City is not segmented strictly to domains any more. Interoperability is powered by the platform. The platform is powered by data and governance.

The model itself consists of elements that are represented in international reviews or the strategic level smart city and spatial development documents we have investigated during the original research of ours. Our research was based on semantic analysis: words and expressions were found to represent smart city ideas no matter what dimension of the smart city was spotted. Five strategic documents of five large cities in Hungary were analysed, primarily seeking for the selected words and expressions, secondly identifying the model elements themselves and their representation. Eight items (sets) were defined as a vivid combination of the reviewed studies and our own findings assembled: Governance, Data, Technologies, Stakeholders, Aims and attributes of Smart City, Way of Life - People - Welfare, City domains and projects, Regionalisation.

The other question we aimed to answer through our analysis of strategic documents was whether the smart city concept appears as in international studies. We found that all the items of international theories that are shown in a unique way in our model are represented although at a different level of extent. This means that the analysed smart city strategies reflect mainstream smart city policies while also differ from one another conveying local specificities. 


\section{Bevezetés}

Az okos város, fenntartható város, élhető város, intelligens város, digitális város kifejezések visszavezethetőek a városfejlődési, valamint technológiai evolúció azon állomásához, amely a kétezres évek elejétől kezdve meghatározza a szakmai és a tudományos közbeszédet (Albino et al. 2015). Az okosváros-koncepció létrejöttének alapját a technológia változása, valamint a technológiákra épülő új szolgáltatások iránti igény biztosította. A technológia fejlődése lehetővé tette, hogy a városi tér egy új dimenzióval, a virtuális dimenzióval gazdagodjék. Ez a virtuális dimenzió napjainkra a város vezetői és müködtetői, valamint a város polgárai, vendégei számára egyaránt kinyílt, természetesen más-más funkciók, rendszerek, felületek, adatok képében.

A tanulmányban az okosváros-koncepció elméleti meghatározását követően az okos város stratégiai modellek, illetve a stratégiát megalkotni és megvalósítani hivatott, bevonó jellegű városvezetési módszertan legfontosabb attribútumait vesszük lajstromba, kiemelve az adatot mint az okos város mozgásban tartásáért felelős másik legfontosabb tényezőt. Abból indulunk ki, hogy az innovatív, komplex, magas szintű és sokrétủ kompetenciát megkövetelő, adatalapú technológiai megoldásoknak innovatív városirányítási technikákkal, nyitott, részvételi alapú kormányzási módszertannal kell együtt járniuk, és mindennek az okos város stratégiai dokumentumokban is vissza kell tükröződnie.

Azzal a hipotézissel élünk, hogy az okosváros-stratégiák nyelvezetét átitatja az okos város terminológia, függetlenül attól, hogy elméleti, menedzsment- vagy informatikai szemszögből vizsgáljuk azokat a szakirodalomban elérhető modellek alapján. Úgy gondoljuk, hogy ezekben a dokumentumokban nem kizárólag stratégiai víziókat találunk, hanem azokat olvasva az adattól, a szakpolitikai területeken át, a governance módszertanon keresztül eljutunk az emberig, avagy az élhetőbb városokig. Azt vélelmezzük, hogy a stratégiákban azonosíthatók és halmazokba rendezhetőek azok a célok, prioritások, outputok - szavak, kifejezések, terminusok - amelyek az okos város komplex rendszerét alkotják, illetve azt strukturálisan jellemzik.

Kutatásunk során szemantikai vizsgálatot végeztünk öt hazai nagyváros okos város stratégiai, vagy annak hiányában, településfejlesztési dokumentumán. A munkánk során megkerestük a kapcsolatot az elméleti hívószavak és az elkészült stratégiai dokumentumok nyelvezete között, majd elvégeztük a szükséges halmazalkotási lépéseket, aminek eredményeként egy stratégiai szemléletü, adatközpontú, kormányzási fókuszú, az elméletet és a pragmatikus megvalósíthatóságot szintetizálni képes okos város ökoszisztéma modellt építettünk fel, a dinamikáért felelős kulcstényezőkkel és egyensúlykereső attitűddel. 


\section{Az okos város sziluettje: kísérlet az okos város meghatározására}

A városok digitalizációja az e-government rendszerekkel kezdődött, amelyek lehetővé tették az online ügyintézést az ezredforduló környékén (Fang 2002). Néhány évnek kellett csupán eltelnie, és ma már az okosváros-koncepcióban éppoly fontos helye lehet egy mesterséges intelligenciát használó közlekedésvezérlési rendszernek, mint egy okos mérőkön alapuló villamoshálózatnak, vagy az appoknak, amelyek a turisztikai látványosságokról adnak tájékoztatást (Dijk, Teuben 2015). A digitalizáció átszövi az okos város valamennyi rétegét. A technológiák alkalmazása önálló szigetszerủ megoldásként önmagában is jelentős hatékonyságjavulást, jobb döntéseket, gyorsabb beavatkozást, kisebb terhelést, alacsonyabb szintủ energiafelhasználást, kényelmesebb ügyintézést eredményez. Ha azonban az egymásra épülő elemek együttműködése rendszerszerűen, koncepcionálisan megtervezetten valósul meg, az további előnyök realizálását teszi lehetővé az alrendszerek felhasználói, valamint a város vezetése számára is, úgy operatív, mint stratégiai szinten (Paskaleva et al. 2017).

Az okos város központi mozgatórugója a városokra értelmezett versenyképesség, a vonzerő, vagy a területi tőke akkumulációs képessége (Rechnitzer 2016), illetve az ebből fakadó magasabb szintű tudáskoncentráció és a város lakói számára biztosított jobb életminőség. A rengeteg technológiára vonatkozó hivatkozás ellenére, az okos város középpontjában az ember és a jobb életminőség áll (Hanák 2018). A technológia valójában a szolgáltatások szintjét emeli a digitális ember elvárásaihoz. Ezért tapasztaljuk azt, hogy az okosváros-stratégiák központi célkitüzései között - lásd Bécs vagy Edmonton példáját - gyakran találkozhatunk az életminőség, az élhetőség javításának stratégiai céljával (www.smartcitywien.at; www.edmonton.ca/city_government/documents/). Ezzel is összefüggésben, az okos városok ,analóg” társaiknál hatékonyabb, vonzóbb, unikálisabb szolgáltatásokat tudnak nyújtani polgáraik számára. A városok közül az okosabb város kerül jobb pozícióba egy olyan világban, ahol az erőforrások tekintetében az előny egyre inkább az ember - adat - technológia köré szerveződik (Dijk, Teuben 2015). Elképzelhető, hogy az okosváros-képességek olyan erőforrássá válnak, mint a hagyományos fizikai erőforrások. Szemben azonban a hagyományos erőforrásokkal, az okosvárosképesség nem kötődik egyetlen vagy néhány szakterülethez (iparághoz, domainhez). Az okos város jellegében multidiszciplináris, kapcsolódás alapú. Kiterjedése inkább horizontális, semmint vertikális irányú (Bélissent et al. 2010; Sallai 2018). Hozzáfüzhető, hogy ez utóbbi jellemzői alapján kiemelkedően alkalmas arra, hogy hozzájáruljon a társadalmi, gazdasági, kulturális és környezeti szempontokból fenntartható város létrehozásához.

Az előbbi tényezőkre figyelemmel az okos város meghatározására nem jött létre teljeskörüen elfogadott, általános és egységes definíció (Starr, Smith 2018). A meghatározások jelentős változáson mentek át az elmúlt szük tíz esztendő alatt. Ahogy a paradigma elhagyta a műszaki, technológiai gyökereit, úgy vált ál- 
talánosabbá, egyre inkább menedzsmentfókuszúvá, pragmatikusabbá, ugyanakkor elvontabbá. A Forrester Research egydimenziós meghatározása szerint az okos város felhasználja az információt és a kommunikációs technológiákat, hogy tudatosabban, hatékonyabban és interaktívabban működtesse a város kritikus infrastruktúráit, szolgáltatásait (Bélissent et al. 2010).

Kontextuálisabb álláspontot képvisel Pereira, aki úgy véli, hogy az okosváros- koncepciót egyfajta keretrendszerként kell értelmezni, ahol a technológia, a kormányzás, a társadalom és a fizikai környezet erőforrásai a város stratégiai céljainak szolgálatába állíthatók. Nézőpontja szerint a komplex városi rendszer elemei között az informatika létesít kapcsolatot, s ennek a kapcsolatnak a minősége erősen befolyásolja a város versenyképességét, hiszen az alapvető adatkapcsolatokra épülnek a magasabb szintű városi szolgáltatások, a város valamennyi releváns dimenziójában, amelyek: emberek, gazdaság, kormányzás, mobilitás, környezet (Pereira et al. 2018).

Effing (2017) nézőpontjából az okos város együttműködő partnerek közös víziójának a megtestesülése, konszenzuson alapuló célok, hangsúlyos innovativitás és kockázatkezelés mentén. Az okosváros-koncepció keretében a humán és a társadalmi tőke, valamint a hagyományos és a kommunikációs infrastruktúra táplálja a fenntartható gazdasági növekedést, biztosítja a magas életminőséget, a természeti erőforrások bölcs kezelését a bevonó típusú városvezetési módszertanok alkalmazásával.

Gondolatmenetünk szempontjából a továbbiakban kiemelt jelentőséggel bír Paskaleva négy kulcsdimenziót meghatározó definíciója, amelyet lényegében szintetizáló modellünk kiindulópontjaként értelmezünk. Szerinte az okos város az adatok, a stakeholderek, a technológia és az együttműködés fogalmaival írhatók le (Paskaleva et al. 2017). Az okos város irányításának tehát ezekre az alapvető elemekre kell kiterjednie; ez első ránézésre egy nagyon leegyszerüsített irányítási keret. Bonyolult vezetési mátrixot állítunk azonban elő, ha a fenti négy szempontot érvényesíteni akarjuk az okos város funkcionális területeire. A területek számossága, jellege, komplexitása, mérete, tőkeigénye, relatív idoérzékelése rendkívül eltérő, ezért a szakmai területek adatalapú rendszerbe foglalása, a domain területek soha korábban nem tapasztalható egymásra épülésének és integritásának megvalósítása multidiszciplináris megközelítést igényel (Effing 2017). ${ }^{1}$

Meglátásunk szerint Effing, s főleg Paskaleva gondolatai esszenciális, kézzelfogható, ugyanakkor nyitott és széles látókörű értelmezési tartományt nyújtanak az okosváros-fogalom számára a hazai okosváros-elemzés tekintetében. Kielégítő és arányos módon jelenik meg bennük a Szarek-Iwaniuk és Senetra $(2020,5$.) szerzőpáros elmélete az okos városok fejlődésének három generációjáról. Az elmélet lényege, hogy nem csak a városok smart city-vé válása tekinthető transzformációs folyamatnak, nemzetközi léptékben maga az okos város koncepciója is evolúción megy keresztül, amelynek magját a civil részvétel jelenléte és minőségi változása adja. Napjainkra már három okosváros-generációt lehet elkülöníteni: 
az elsőben a technológia játszik kulcsszerepet, és alapvetően a városmenedzsment hatékonyságának javítását célozza (Okos város 1.0); a második generációs okos város a helyi kormányzatok bevonó jellegü politikáin és az általuk kezdeményezett programokon alapul, ahol a modern technológiákkal már egyenrangúvá válik az életminőség javításának és a helyi kormányzásnak a célkitűzése (Okos város 2.0). A harmadik generációs városok (Okos város 3.0) tekinthetők a legfejlettebb smart city-knek, melyek a bevonás mértékének növekedése mellett a közösségi kontroll, a közösségi kezdeményezés és irányítás, valamint a közösségi létrehozás (co-creation) számára is utat nyitnak. Hozzá lehet ehhez tenni, hogy az utóbbi jegyekkel bíró, alulról is szervezett okos városok a kelet-közép-európai régióban egyelőre nem jellemzőek (Szarek-Iwaniuk, Senetra 2020).

A két modellt egyesítve az 1. ábra foglalja össze. A következő fejezetben ismertetett okosváros-modellek áttekintésekor, illetve a tanulmányunk további fejezetei során ezen meghatározások lenyomatait keressük.

1 ábra: Az okos város stratégiai szempontú értelmezése

The strategic interpretation of the smart city

Stakeholderek

Közös víziók

Szakpolitikai

prioritások

Innováció

Együttmúködés

Adat

Kockázatkezelés

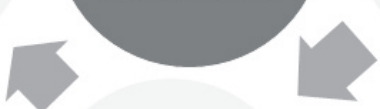

Technológia

Forrás: Paskaleva et. al 2017 és Effing 2017 alapján saját szerkesztés

\section{Az összekapcsolt, adatvezérelt város elméleti és gyakorlati modelljei}

Ahogy arra már utaltunk, a technológia természetesen nem megkerülhető egy olyan rendszerben, ahol a hozzáadott értéket a digitalizáció biztosítja. Big-data, 
mobil eszközök, IoT (Internet of Things) szenzorok, IT biztonság, mesterséges intelligencia algoritmusok, applikációk százai-ezrei kapcsolódnak össze az okosváros-hálózatban (Karabegović 2017). Mért, valós idejü adatok alapján születnek a döntések, úgy a tervezési, mint az operációs szinteken (Pereia et al. 2018).

Az okos város logikai modellek kísérletet tesznek arra, hogy egységes és arányos felépítésben utaljanak az okos város komplex rendszerére és egybeforrasszák a sokrétü tényezők mindegyikét. Impozánsak a városok domain területeit hangsúlyozó modellek, amelyekben a város alrendszerei, azaz az ágazatok mentén épülnek fel az összefüggések (Lados, Horváthné Barsi 2011).

Meg kell említenünk Giffinger okosváros-modelljét, amely az európai okos városok összehasonlítására keletkezett (Giffinger et al. 2007). A modell elemei, amelyek egyúttal az okos városok EU-ban alkalmazott (ESCI European Smart City Index) jellemzőit, illetve sorrendjét meghatározó főbb szempontcsoportok is (Manville et al. 2014), a következők: okos gazdaság, okos emberek, okos kormányzás, okos mobilitás, okos környezet, okos életkörülmények. A modellel a magyarországi ajánlások között is találkozunk, többek között a Lechner Tudásközpont metodikai útmutatójában (Dobor et al. 2015).

Cassandras más szempontok szerint építi fel modelljét (2. ábra), amelyben egyértelműen megjelenik az adat mint kiemelt, önálló tényező. Az okos város ez

2. ábra: Az okos város CPS rendszere

The CPS system of the smart city

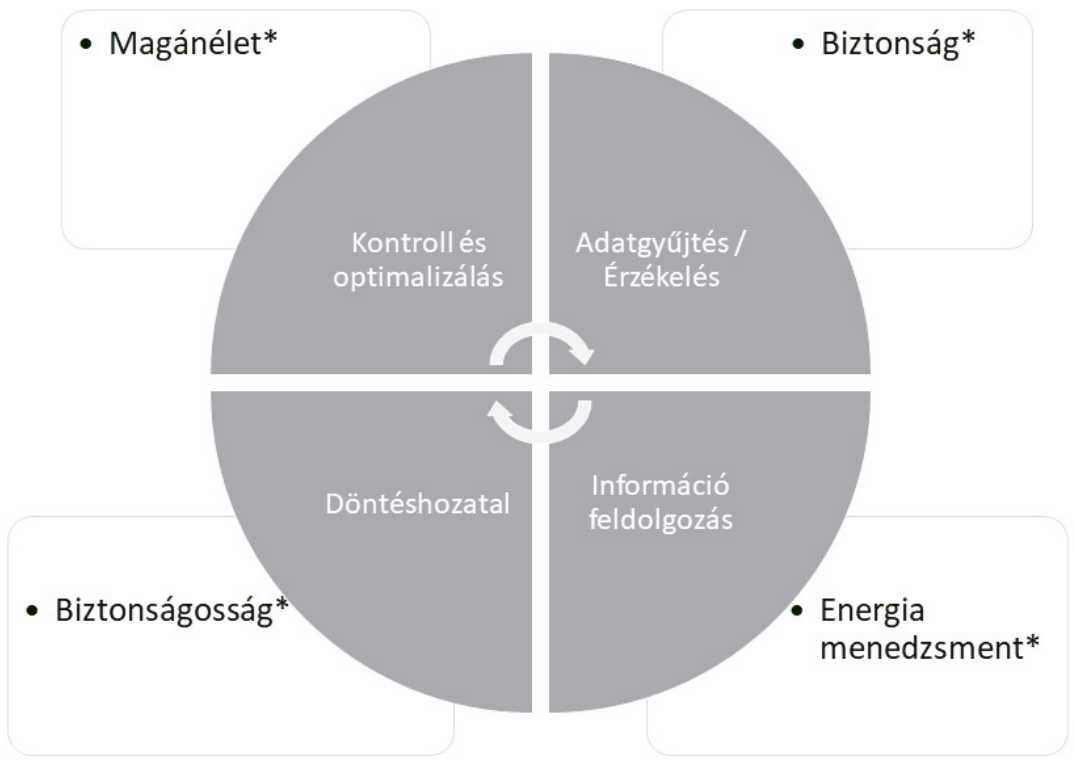

* szempontjainak figyelembe vétele, az adatfeldolgozás teljes folyamata során. 
esetben egy dinamikus, komplex, adat- és érzékelésvezérelt CPS (Cyber Physical System) rendszer, amely folyamatosan végzi az erőforrások optimalizációját és reallokációját, szem előtt tartva az adatbiztonság aspektusait (Cassandras 2016).

A nemzetközi tanácsadó és informatikai vállalatok a rendszerek, a platformok, az adatok, az adattárházak és azok kapcsolatainak fontosságát hangsúlyozzák. Ezekre az elemekre építik a logikai rendszereiket: az okosváros-megoldások digitális kapcsolatot létesítenek a hagyományos infrastruktúra fizikai elemei és a modern technológiai rétegek (IoT, hálózat, alkalmazások, adatalapú rendszerek, IT biztonság) között (Woetzel el al. 2018; Vida 2018), ezért az okos város informatikai vagy digitális platformja vagy önálló megoldásként valósítható meg, vagy a szoftverfejlesztő vállalatok meglévő általános megoldásainak alkalmazásával építhető fel (pl. CRM, middleware, portál, data hub). Az Accenture nemzetközi tanácsadó vállalat például modelljében kiemeli a városi szolgáltatások domain szakterületeit és ezek alá strukturálja az Intelligens Platformot, ami az Intelligens infrastruktúra, Tervezés és Stratégiakészítés, valamint Menedzsment és Governance silókból áll. Az Intelligens Infrastruktúra Platform feladata az adatfeldolgozás teljes folyamatának kezelése az adatgyüjtéstől a döntéselőkészítésig, az adatok és a kommunikációs folyamatok segítségével (Berthon 2011). A világelső relációs adatbázis rendszert gyártó Oracle technológiai vállalat is az adatfeldolgozást és a rendszerek közötti kapcsolatot helyezi fókuszba (Carr et al. 2011), míg a vállalatirányítási rendszereket szállító SAP szoftver vállalat a mesterséges intelligencia és az egyszerüsített folyamatok alkalmazását emeli a középpontba (Klein 2020). A hardvergyártók is komplex megoldásokkal jelennek meg az okosvárosmegoldások piacán (pl. IBM, Siemens, Cisco, Dell EMC). Rendszereik együttmüködések eredményeként, integrált rendszerként jönnek létre az IoT eszközöktől az adattároló koncepciókig (Khan et al. 2017; Allam, Newman 2018; Sallai 2018; Kovács 2018).

Figyelemre méltó, hogy a tudományos megközelítés és a megélt okos város szintézisét célozza létrehozni az IMD (Institut for Management Development 2020) okosváros-rangsora, melynek középpontjában a helyi lakosok állnak, vagyis az ember. 2020-ban a világ 109 városát mérő ún. Smart City Index (SCI) a megvalósult és fenntartható okos várost kéri számon öt kulcsterületen gyüjtött információk segítségével, azokat két fó pillérre vonatkoztatva. Míg az infrastruktúrapillér a városok meglévő infrastrukturális ellátottságát veszi számba, addig a technológiapillér a kínált és elérhető szolgáltatásokat és alkalmazásokat méri az egészség és biztonság, a mobilitás, a tevékenységek, a lehetőségek és a kormányzás területén. Sokat elárul a módszertanról, hogy a lakosok percepcióját összeköti az adott város ENSZ Human Development Index alapján mért gazdasági fejlettségével. A rangsor dobogós helyezéseit Singapore, Helsinki és Zürich foglalja el, míg Budapest a 77. helyre került (a többi magyar város egyelőre nem szerepel a kimutatásban.). Ha csak az okos városok kormányzási jellemzőire vonatkozó szempontokat tekintjük, látható, hogy komoly súlyt képvisel az indexben a helyi döntéshozás 
nyitottsága és állampolgári ellenőrizhetősége, nem beszélve a korrupció csökkentését elérni hivatott átlátható pénzügyi gazdálkodásról.

Az öt magyarországi okosváros-stratégia szemantikai elemzését tartalmazó későbbi fejezetben kísérletet teszünk arra, hogy empíriával alátámasztott módon összekapcsoljuk a fent ismertetett megközelítéseket, egyensúlyt keresve a horizontális (domain alapú) és a vertikális (menedzsment-, illetőleg a technológiai) szempontok között. Figyelmünket a következő két fejezetben a feltételezésünk szerint két dinamizáló tényező felé fordítjuk, vagyis a kormányzás (e-government) és az adat rendszerszintű, részletes elemzésére.

\section{Az e-government mint közösségiérték-teremtő eszköz}

Az e-government hagyományosan az online szolgáltatásokat, magyar szóhasználatban az elektronikus ügyintézést fedi, mely a különféle információs és kommunikációs technológiák (továbbiakban IKT) alkalmazásán alapul a közigazgatási eljárások gyorsabb és olcsóbb lebonyolítása érdekében (Balogh, Budai 2018). Ezzel elérhető a lakosság és a vállalkozói szféra tehermentesítése, s egyúttal a kormányzási teljesítmény javulása. Tagadhatatlanul ebbe a fogalmi körbe tartozik az információk nyilvánossága, illetve az azokhoz történő hozzáférés biztosítása információs portálok, applikációk üzemeltetésével a nap 24 órájában. Mi több, ezzel összefüggésben sor kerül a közigazgatás és az ügyfelek közötti elektronikus kommunikáció csatornáinak kiépítésére is. Ebben az értelemben az e-government az általános fogalom, amelynek adaptációja nem történhet értékmentesen.

Ugyanis az IKT sokcélú alkalmazása során változnak és fejlődnek azok a közösségi értékek, amelyeket elvárásként az állampolgárok, vállalkozások, civil szervezetek a közigazgatás müködéséhez és a közszolgáltatásokhoz kapcsolnak. Olyan kölcsönhatások jönnek létre, amelyek alapjaiban megváltoztatják az említett szereplők egymáshoz való viszonyát. Éppen ezért a nemzetközi kutatás már bizonyította, hogy az e-kormányzás eredőjeként azonosíthatók bizonyos közösségi értékek, amelyek egyértelmüen az IKT generálta folyamatoknak köszönhetően fejlődtek (Twizeyimana, Andersson 2019) (3. ábra).

Tény, hogy az állampolgárok és a vállalkozások igénye világszerte növekszik a nyitottabb, transzparens és hatékony kormányzás iránt, hiszen a digitális technológiák lehetővé teszik a hatékony tudásmenedzsmentet, a szolgáltatások integrációját, vagy éppen a közpénzek elköltésének ellenőrzését az adatok nyilvánossá tételén keresztül. Ennek következtében az e-government fokozottan hozzájárulhat a kormányzatok és az állampolgárok közötti bizalom építéséhez. Sőt, lehetőséget teremt a kétirányú információ- és tapasztalatmegosztásra, azaz a közszolgáltatások együttes megújítására és a kooperációra épülő, tényalapú (evidence-based) közpolitika formálására (Mechant, Walravens 2018). 
3. ábra: Az e-governmentet jellemző közösségi értékek hat dimenziójának általánosítása három fö szempontban

Six dimensions of the public values that characterize the e-government in three general aspects

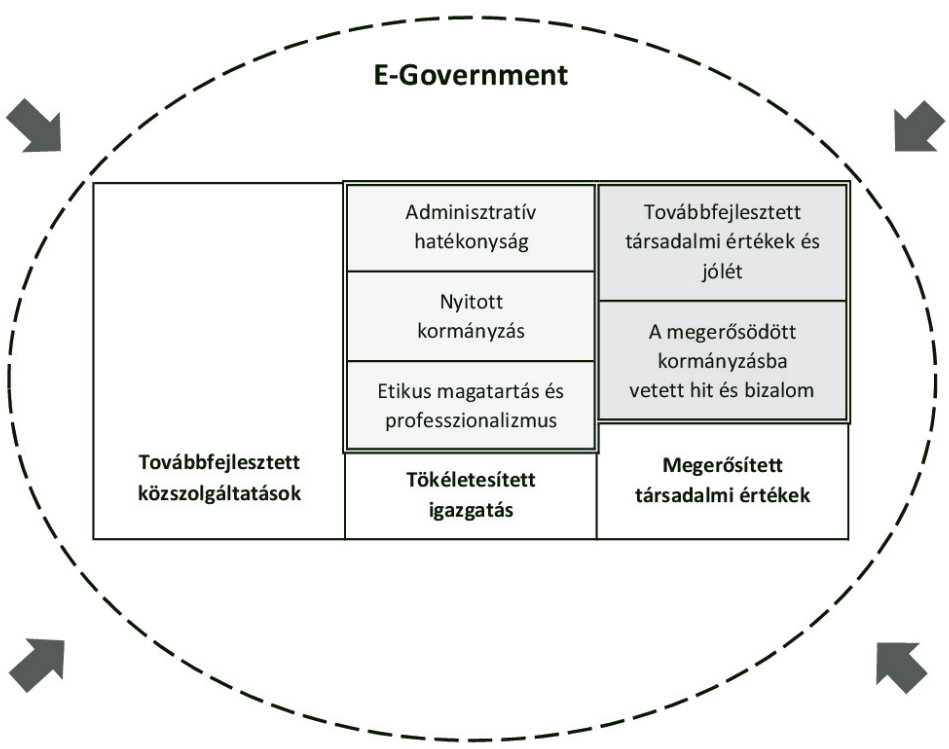

Forrás: Twizeyimana, Andersson 2019, 170.

E helyütt fontos kitérni az e-government és az e-governance fogalmi megkülönböztetésére. A public governance fogalma a hatékony kormányzás értelmében a New Public Management (NPM) időszak leáldozása idején, az 1990-es évek közepén jelent meg, tekintettel arra, hogy az NPM reform agendája ellentmondásos és konfliktusos volt (Andrews, Entwistle 2014). A public governance felfogás a közszektort ismét állam- és társadalomelméleti kérdésekkel kapcsolta össze, és ily módon a politikai kormányzás szinonimájaként használják. A kormányzás azon típusáról van szó, amely a közigazgatás müködését stratégiai alapokra helyezi, átfogó célmeghatározást és mérhető eredményeket vár tőle. Sőt, a korábban, az NPM idején fokozottan érvényesülő piaci mechanizmusok háttérbe szorítása mellett, a tervek megvalósítását erőteljesebb állami szabályozás és ellenőrzés alá vonja. Ezen túlmenően, elterjedt nézet szerint a hatékony kormányzási mechanizmus feltétele, hogy a közszféra a szakpolitikák formálásába és a tervezési folyamatokba minél szélesebb körben bevonja a helyi szereplőket, illetve lehetővé tegye számukra, hogy egyes döntéshozási folyamatokat befolyásoljanak (Benz 2004; Osborne 2010). Miután a tervezés maga is kormányzási eszköz, és az okosváros-koncepció rendszerint egy fejlesztési stratégián és annak megvalósításán alapul, a kormányzás eleve áthatja az okos város működését.

Noha az e-government eleinte a közigazgatás belső folyamatainak modernizálására irányult, az okosváros-koncepció létrejötte óta lényegesen nagyobb lép- 
tékben történik a közszféra működésének innovatívvá tétele az adatok gyüjtése, összekapcsolása és integrálása révén. Ez magas minőségű szolgáltatási teljesítményben ölt testet, és komplex partneri együttmúködést felételez a legkülönfélébb stakeholderek között, amely kapcsolat a Triple Hélix-modell különböző formáival írható le (lakosság, civil és akadémiai szféra, vállalkozások stb.) (Mechant, Walravens 2018; Józsa 2019). Elmondható tehát, hogy az okosváros-koncepció az e-government eredeti fogalmán lényegesen túlmutat, mivel alkalmas arra, hogy egyrészt kidomborítsa a jó kormányzásban megtestesülő közösségi értékeket (public value), másrészt hogy segítségével megvalósuljon a legkorszerűbb városmenedzsment.

Az okos városi környezetben az infokommunikációs technológiáknak (ITK) köszönhetően a helyi önkormányzatok a kooperáció érzékelhetően újabb formáit találják meg, ami elvezet a használók tényszerü bevonásához a szolgáltatások, közösségi terek, dolgok közös alakításában. Egyes szerzők már a komplex platformalapú városi ökoszisztémákról írnak, illetve megerősítik, hogy a szociális média, a közös tanulási folyamatok az állampolgárok számára új lehetőséget nyitnak a helyi kormányzásban való részvételre (Zygiaris 2012). Ez pedig magával hozta az ún. smart governance evolúcióját és a közösségi elkötelezettség megerősödését, amit Glasgow smart governance platformja modellértékủen példáz (Leleux, Webster 2018).

Glasgow, Skócia legnépesebb városa egy pályázat nyerteseként „smart city” stratégiát valósított meg a "Jövő városa Glasgow" (The Fututre City Glasgow, továbbiakban FCGP) címmel 2013 és 2015 között. A mi szempontunkból a smart governance égisze alatt megvalósított projektek bírnak jelentőséggel, melyek három közös komponensét az infokommunikációs részvételi módok, a governance és a fenntarthatóság szolgáltatta.

Mit is jelent a nagyváros számára az okos kormányzás? Különféle technológiák közvetítésével működő állampolgár-központú modellt, amely az együttmüködésre, értékek és dolgok együttes megalkotására épül, s aminek keretét például a hackathon, ${ }^{2}$ a living labek, ${ }^{3}$ a gamification, ${ }^{4}$ a nyitott adatbázis stb. szolgáltatják (Leleux, Webster 2018). Azaz számos olyan új értékteremtő kooperatív eszköz adaptációja zajlik, melyeknek elfogadott fordítása hazánkban még kevéssé létezik. E folyamattal összefüggésben próbálkoztak az állampolgári elkötelezettségnek (citizen engagement) az állampolgári részvételtől (participáció) való megkülönböztetésével is, ugyanis lényegi különbségnek tartják, hogy az előbbi kétirányú aktív kapcsolatot, szándékolt dialógust feltételez az állampolgárok és a közszféra döntéshozói között, míg a társadalmi részvétel akár egyoldalúan a polgároktól, tehát az alulról jövő kezdeményezésekre is szorítkozhat.

A téma elméleti alapjaihoz visszatérve, tény, hogy a post-NPM reformok számos uniós tagországban kiszélesítették az állampolgárok bevonásának technikáit, amelynek napjainkban két elérő szemléleti bázisa érzékelhető. Az állam egyik megközelítésben nem érintettként (stakeholder), hanem használóként, fogyasz- 
tóként, ellátottként tekint az állampolgárokra, s ily módon a velük való kommunikációt a szolgáltatásokkal kapcsolatos elégedettségmérésre szűkíti le. Ezzel ellentétben a másik szemlélet az állampolgári bevonás participáció-technikáinak alkalmazását támogatja, ami szervesen kapcsolódik az e-governance-hoz. Rendkívül kifejező, hogy de Vries $(2002,94$.) a kormányzat és a társadalom közötti interakciók relációjában az ügyfélstátuszt a hierarchikus viszonyokhoz, míg a partneri pozíciót a horizontális érdekviszonyokhoz sorolja. Mindez nem mond ellent annak, hogy mindkét hatalmi reláció a felek közötti megegyezést célozza.

Szerzők (Schwab et al. 2017) azt sugallják, hogy ha a ,jó minőség” (good quality) nem pusztán egy belső szervezeti felfogáson, hanem részvételi eszközök alkalmazásán is alapul, akkor ez a kooperatív szemlélet képes fejleszteni a helyi demokráciát és a közszféra működését. Vagyis az állampolgári igények és vélemények megismerése a hatékony kormányzáshoz szükséges adatok értékes forrása. Fogalmazhatunk úgy is, hogy az adott közfeladat ellátásával érintettek (stakeholderek) integrációja, a velük való együttmüködés és kommunikáció napjainkra a szolgáltatásmenedzsment lényeges eszközeivé váltak. Ebbe a személyi körbe beleértendők egyfelől a közköztisztviselők és alkalmazottak, az állampolgárok, az ellátottak, másfelől a stratégiai érdekeket megjelenítő érdekvédelmi szervezetek, a szolgáltatást nyújtó gazdasági társaságok, non-profit szervezetek stb.; összefoglalóan, akik a sikerekhez hozzájárulhatnak.

A vázoltakból következik, hogy a smart governance elsősorban nem technológiai kérdés, hanem az intézményi változások komplex folyamata, aminek elméleti háttere még kidolgozásra vár. A folyamat szerves része az állampolgári elkötelezettség és öntudat fejlesztése, nem mellesleg a digitális műveltség kiterjesztése, illetve a digitális kirekesztettség mérséklése. El kell tehát ismerni, hogy az IKT a kommunikáció és együttműködés, valamint a kormányzás új formái számára nyitott utat. Az okosváros-kormányzás a kölcsönösségen és bizalmon alapul. Lehetővé teszi, hogy a szakpolitikai döntéshozás tekintetében a nyilvánosság kontrollja érvényesüljön, és a helyi döntéshozás transzparenssé váljon. Összességében tehát megfeleltethető a good governance (jó kormányzás) normatív tartalmának, különösképp a nyitottság, a részvétel és elszámoltathatóság követelményének (lásd Sigma Paper 1999).

Témánkkal összefüggésben a közigazgatási oldal is említést érdemel, ugyanis az okos városoknak igazgatásszervezési és vezetési kihívásoknak is meg kell felelniük. Nemeslaki (2017) szerint az a városvezetéstől új vezetési ismereteket valamint szervezeti kultúrát kíván meg, amit sokszor akadályoz az ügyfelek alárendeltségére épülő klasszikus közigazgatási szemlélet. Következésképp maguknak a döntéshozóknak is be kell járniuk az e-government érettségi szintjeit, azaz az IKT egyszerü döntéstámogató szerepétől el kell jutniuk a folyamatok áttervezésén és új folyamatszervezési feladatokon át a magas szintű partneri hálózatok kialakításáig. 
A fentiek tükrében szakmailag aggályosnak tekintjük azt a megközelítést (lásd Szalai 2020), mely az okosváros-koncepciót az ún. neoliberális várospolitika megnyilvánulásával azonosítja. Cáfolhatónak tartjuk azt a véleményt, amely szerint az okosváros-koncepció kizárólag a helyi növekedési koalíciók és technológiai csúcsvállalatok üzleti és profitcéljainak szolgálatában áll, s olyan eszköz, amely korlátozza a demokráciát.

\section{Az adat és az adatalapú „okos kormányzás”}

Az okosváros-koncepció legelemibb alapegysége az adat, és az abból következő információ és új tudáselem, ami felhasználható a város kormányzásában a számadatokon alapuló, esetenként algoritmizálható döntések során. Az adat természetesen akkor jelent értéket, ha felhasználása új értelmet, új minőséget, pragmatikus nézőpontból új városi szolgáltatást, javuló életminőséget, vonzóbb lehetőségeket eredményez. Az okos városok adatgyárak lesznek, ahol az adatforrások a lehető legnagyobb variancia mellett kapcsolódnak egymáshoz. Az adatrekordok egymás mellé illesztése, elemzésük, a szakterületi rendszerek összekapcsolása pedig korábban nem észlelhető összefüggésekre világít majd rá (Achaerandio et al. 2012).

$\mathrm{Az}$ okos város adatmenedzsmentje ezért organikusan összekapcsolódó rendszerek, funkciók, rétegek halmazán keresztül hoz létre új, a döntéshozatal során felhasználható információt. Az okos város filozófiája mentén felismerhetjük, hogy mindez nagymértékben rímel az „okos kormányzás” ismérveire, az adatmenedzsment tekintetében jellemző terminusokkal kifejezve: adatazonosítás, adatgyüjtés, adatgenerálás, adatmegosztás és adatmenedzsment, adatfelhasználás, adatörökség-kezelés, projektkontextus (Paskeleva et al. 2017).

A mért elemi értékek a speciális algoritmusok kalkulációit követően a riportok (adatfeladások) során újabb és újabb aggregációs lépésen esnek át, majd adatelemző eszközök segítségével (Big Data, BW, BI) manuálisan vagy automatikusan trendek, becslések és döntések számíthatók belőlük (Vida 2018). A számértékek természetesen önmagukban nem elégségesek az okos város adatalapú irányításához. A stratégiai célokat KPI-kre (Key Performance Indicator), mérheto” változókra kell lebontani. A KPI táblák szakterületi bontásban, rendszer/alrendszer/mért érték bontásban épülnek fel. Egy-egy területen - a mérés lehetőségeinek függvényében - több KPI is meghatározható, skálázott célérték-definíció mentén. Triviális, hogy a KPI-k csak konkrét projektek, rendszerek, folyamatok esetében értelmezhetők. A KPI-k számossága szakterületenként eltérő lehet, a mért értékek alábontottsága is különbözhet, annak függvényében, hogy milyen számítási és adatfeldolgozási háttér áll a város rendelkezésére (Hara et al. 2016; Nielsen et al. 2013; Bueti 2017; Angelakoglou et al. 2019; Bakonyi 2018). 
Az okos kormányzást az adatok minél nagyobb mértékű és minél inkább integrált kezelése támogatja. Az adatalapú „okos kormányzás” legmagasabb szintű és legkifinomultabb technológiai megvalósítása, a tanulmányban korábban (irányítási/informatikai) platformként hivatkozott intelligens adatközpont kialakítása, ahova beérkeznek az adatok, és ahol meghozhatók a döntések, majd azok az interfészeken keresztül visszaadhatóak a szakterületi, illetve ágazati rendszerekbe, miközben a mérés, az értékelés, a szabályrendszerek leképezése is ugyanitt történik. Ez valójában egy okos város vezérlőpult, amely az adatlefúrás lehetőségének biztosítása mellett, vizuálisan mutatja a város állapotát, a mért értékek, az adatok, az absztrakciók, a terv-tény értékek státuszát (Kourtit, Nijkamp 2017).

Gondolatmenetünk alapján az okos várost az e-governance és az adatok irányítási rendszerbe való adekvát integrálása viszi előre. Ezen két tényező kiegyensúlyozott egymás mellett létezése tartja irányban az okos város fejlődésének pályáját, ez a két tényező emeli magasabb szintre (analóg városból okos város) a város egyéb korábban ismertetett modellszintű dimenzióit. Nem állítjuk, hogy ez a két tényező kiemelt fontosságú lenne a többi dimenzióhoz mérten. Megállapításunk arra vonatkozik, hogy ha az okos várossá válás motorját keressük, talán ezek lehetnek a mindenhol megjelenő, mindent átitató, dinamizáló tényezők.

Ez a felismerés vezetett ahhoz, hogy megkíséreljük igazolni, vajon a magyar nagyvárosok okos város stratégiáiban megjelennek-e a governance-ra, az adatra, illetve az okosváros-modellek további kategóriáira, halmazaira vonatkozó utalások, kifejezések, szavak, szókapcsolatok. Vajon a dokumentumok megfelelnek-e a modelleknek, vagy a modellek megerősítést nyernek-e a dokumentumok által, esetleg találhatunk-e olyan dinamikus modellt, ami egyesíteni képes a korábbi statikus megközelítéseket? Mielőtt ezekre a kérdésekre választ találnánk, a következő fejezetben kapcsolatot teremtünk az eddig áttekintett elméletek és az okosváros-stratégiák, illetve azok megvalósítása között.

\section{Az okos város stratégiakészítésének komplexitása}

A technológia olyan gyorsan fejlődik, hogy az okosváros-stratégia tervezésére nem lehet sok időt szánni, ellenkező esetben, mire megvalósulna, elavult lesz - fogalmazza meg az álláspontját Middleton (2018). A közösség számára hasznos digitális célok, szolgáltatások kialakítására fordítandó energiákat - az előbbiekben idézett provokatív vélekedés ellenére - természetesen szükséges kanalizálni. Az okosvárosfunkciók megfelelő gondossággal és szakértelemmel elkészített stratégiai tervek nélkül ugyanis csak ad hoc módon (Effing 2017) tudnak szárba szökkenni.

Az okosváros-stratégiák egyszerre vizionáriusak és pragmatikusak, közép-és hosszú távúak, továbbá minden esetben adaptálni kell azokat a helyi adottságokra, lehetőségekre (Achaerandio et al. 2012). Az okosváros-stratégia olyan paradigmákra (digitalizáció), módszertanokra (adatalapú működés), eszköztárra (technológia) 
alapul, amely merőben új.Jellemzően nincs mihez visszanyúlni, a kapcsolódásokat a jövőre vonatkozó elképzelésekből kell megalkotni. Ezért a stratégia a megvalósítás mesterterve. Az okosváros-stratégia egy stratégiai keretrendszer, amely célokat jelöl ki, és megteremti a célok eléréséhez szükséges infrastruktúrát. Várja a szakterületektől az innovatív megoldásokat, miközben a társadalmi egyeztetésen átesett elemek megvalósítása felett őrködik. Az okos várossá válás lépéseit Tuncer elemzéséből vesszük át, amely egyszerre példázza a tervezés és a bevonás fontosságát, valamint illusztrálja a technológia alárendelt pozícióját a stratégiai rendszerben: stratégiakészítés, kompetenciák jogosultjainak multidiszciplináris bevonása, projektformálás, implementációs terv, technológiaválasztás (Tuncer 2017).

Ezzel a struktúrával a makro-, mezo- és mikroszintű szempontok is teret kapnak, valamint lépésről lépésre bevonódnak a kompetenciával bíró stakeholderek. A stratégiakészítés során a város jövőképe, víziója ölt testet, valamint megfogalmazódnak a legfontosabb célok. A bevonás fázisa már a szakterületek között lefolytatandó szakmai vitáknak ad teret. A projektformálás szakaszában jön létre a közösség elköteleződése a kiválasztott projektek iránt. Az implementációs terv a projekt megvalósításának részleteit foglalja magában, végül a technológiaválasztással, a polgárok által megfogalmazott felhasználói élményre vonatkozó elvásások alapján megkezdődhet a megvalósítás (Letaifa 2015). Az okos várossá válás egy véget nem érő folyamat, hiszen a város szolgáltatásait folyamatosan fejleszteni kell az attraktivitási szint fenntartása érdekében.

\section{Öt magyarországi okosváros-stratégia szemantikai elemzése és a modellalkotás}

A kutatásunk során, az áttekintett elméleti tanulmányok és a bennük hivatkozott nemzetközi okosváros-stratégiák tanulságainak elemzését követően iteráló módon, szemantikai elemzéssel elvégeztük öt magyarországi nagyváros (Debrecen, Győr, Székesfehérvár, Szeged, Szombathely) okosváros-stratégiájának összehasonlítását. Pontosabban azokat a városi stratégiai dokumentumokat elemeztük, amelyek elérhetőek az interneten, és közvetlenül vagy áttételes módon tartalmazzák az okos várossal kapcsolatos fejlesztési elképzeléseiket, akár a településfejlesztési stratégia részeként, akár dedikált okosváros-stratégia formájában (1. táblázat).

A szemantikai elemzés során releváns kulcsszavakra kerestünk rá az okos város áttekintett szakirodalma alapján. A szemantikai elemzés módszertana a nyelvészeti tudományokban gyökerezik, és a jelentés tárolására, a jelentés egyértelműsítésére, a szinonimák keresésére, a jelentésazonosság felkutatására, nyelvtani vagy szerkezeti jellemzők azonosítására vállalkozik. A szavak vagy mondatok között felkutatott kapcsolatokat halmazokba rendezve, a találati értékeket matematikai módszerekkel kezelve nyílik mód következtetések levonására, illetve tar- 
1. táblázat: Elemzett okos város stratégiai dokumentumok

The list of the smart city documents analyzed by the research

\begin{tabular}{|c|c|c|c|c|}
\hline Város & Dokumentum jellege & Időtáv & Elfogadás éve & Terjedelem (oldal) \\
\hline Debrecen & $\begin{array}{l}\text { smart city } \\
\text { stratégia }\end{array}$ & $2020-2030$ & 2020 & 68 \\
\hline Győr & $\begin{array}{c}\text { integrált } \\
\text { településfejlesztési } \\
\text { stratégia }\end{array}$ & $2014-2020$ & 2014 & 152 \\
\hline Szeged & $\begin{array}{l}\text { smart city } \\
\text { stratégia }\end{array}$ & $2016-2026$ & 2016 & 172 \\
\hline Székesfehérvár & $\begin{array}{c}\text { integrált } \\
\text { településfejlesztési } \\
\text { stratégia }\end{array}$ & $2014-2020$ & $\begin{array}{c}\text { Felülvizsgálva, } \\
2018\end{array}$ & 151 \\
\hline Szombathely & $\begin{array}{c}\text { integrált } \\
\text { településfejlesztési } \\
\text { stratégia }\end{array}$ & $2017-2030$ & 2017 & 299 \\
\hline
\end{tabular}

Forrás: saját szerkesztés

talmi, jelentéskapcsolatok értelmezésére (Csányi 2020). A módszertan az írott és a verbális kommunikáció elemzésére egyaránt alkalmas, amennyiben a keresett kifejezésekből releváns adatbázis építhető fel (Vincze et al. 2021). Azért választottuk a kutatás alkalmazott módszertanának a szemantikai elemzést, mert a nyelvi kifejezések (fordítások) hordozzák azokat a jelentéstartalmakat, amelyek mentén az okosváros- stratégiák megvalósulhatnak. A kutatás első fázisában hívószavakat gyüjtöttünk a nemzetközi szakirodalom alapján, tudatos szókereséssel, szóadatbázis építéssel. A hívószavak azonosítását követően, a kutatás második szakaszában a kategóriaalkotás, majd a kategóriákból a modell kiérlelése valósult meg. Az öt hazai városi stratégiai dokumentum tekintetében a szóadatbázis alapján direkt keresést, asszociatív keresést, ragozással kiegészített keresést végeztünk. Amennyiben a stratégiai dokumentumok olvasása és a szókeresés során új szó keltette fel a figyelmünket, az imént leírt folyamatot megismételtük valamennyi dokumentum esetében, és az új szót integráltuk a korábban elért részeredményekhez.

Az alkalmazott módszertan komparatív megközelítésében, valamint a jelentéstartalmon alapuló statisztikai összevetésében újdonságnak számít. Azt reméljük, hogy a szinergikus modell éppen azáltal adhat jó közelítéssel magyarázatot az okos város müködésének jellegzetességeire, hogy a stratégiákban leírt teremtő szavak építik fel az általunk rajzolt kategóriákat, és nem fordítva.

Mindösszesen 67 db szót gyüjtöttünk össze hívószó gyanánt. A szavak között gyakran használtunk szinonimákat, továbbá az angol kifejezések magyar megfelelőit, illetve szókapcsolatokat. A keresett szavak ragozott formáit, szótöveit, szóösszetételeit ugyancsak találatnak tekintettük. A szókeresést kiegészítettük hibakereséssel is, vagyis az olyan szavakat, amelyek például fejlécben, láblécben szere- 
peltek, nem tekintettük találatnak. Ugyancsak kiszűrtük azokat a hibás találatokat, amelyek a szövegösszefüggés alapján derültek ki. A keresett szavak köre iteratív módon bővült, olyan módon, hogy ha az öt elemzett stratégiai dokumentum bármelyikében ráleltünk, akkor azt a szót valamennyi dokumentumban megkerestük, akár többször is visszatérve a korábban már átnézett dokumentumokhoz.

Az áttekintett öt dokumentumban mindösszesen 12850 találatot kaptunk. A megtalált, releváns kifejezéseket halmazokba rendeztük. Megkíséreltük azokat a korábban hivatkozott elméleti szerzők, illetve a nemzetközi IT és tanácsadó cégek gyakorlati modelljeinek megfeleltetni. A csoportosítási kísérletek azonban minden alkalommal jelentős számú kimaradó szóhalmazt, hibahalmazt eredményeztek. A keresett, illetve megtalált releváns kifejezések tényszerüen nem illeszkedtek megfelelően a hivatkozott modellek egyikébe sem. Az előbbiekben (az elméleti gyökerű esetekben) sok volt a vízió, a stratégiai célmeghatározás és az ágazati hivatkozás, és kevés az adatra vonatkozó utalás, az utóbbiakban (a gyakorlati indíttatású megközelítésekben) sok volt a technológia, de kevéssé jelentek meg a szakmai domain területek és a governance szempontjai - röviden, nem volt megfelelő a halmazalkotás.

Így többszöri kísérletezést követően, az említett modellek szemléletét megtartva, saját modellt rajzoltunk - az öt stratégiai dokumentum elemzését követően -, amelyben le tudtuk képezni a keresett kifejezéseket, és egyidejüleg tudtuk megjeleníteni az elméleti és a pragmatikus modellek szempontjait. Első lépésben a szavakból egészséges belső arányú, megvalósítható rendszert képeztünk a keresett, illetve megtalált szavak halmazokba rendezése által. A Szinergikus okos város modellünk alapjai azon szó- és kifejezéshalmazok lettek, amelyekbe be tudtuk sorolni a keresett és megtalált szavakat, kifejezéseket, és amelyek ugyanakkor logikailag is megfeleltek az okosváros-struktúrának.

\section{Az adatcentrikus és a kormányzásfókuszú Szinergikus okos város ökoszisztéma modell felépitése}

A modell felépítésében ötvözzük az elméleti, a szakterületi és az informatikai nézőpontot, egyfajta pragmatikus, megvalósítható ökoszisztéma absztrakciójaként. A modell fókuszában a rendszerelemek, a rétegek és a közöttük létrejövő kapcsolatok állnak, és a széles körben elterjedt megközelítésekhez képest kissé háttérbe szorulnak a városi domain területek, valamint a konkrét projektek (4. ábra). Ugyanakkor a modell építése során fontos gondolat volt a bevezető fejezetekben ismertetett két dinamizáló tényező (adat és governance) kiemelése, illetve a megvalósíthatóság és a rétegződés vizuális kifejezése. A modellben igyekeztünk szinergiát teremteni az elméleti és a gyakorlati (városi szakterületeket kiemelő) elképzelések között, ezáltal a modellben összefoglalni az okos város miden alkotóelemét, olyan módon, hogy az a város- és intézményi vezetők, illetve a stake- 
4. ábra: Az adatcentrikus és governance fókuszú Szinergikus okos város ökoszisztéma modell felépítése

The structure of the data centric and governance focused

Synergic smart city ecosystem model

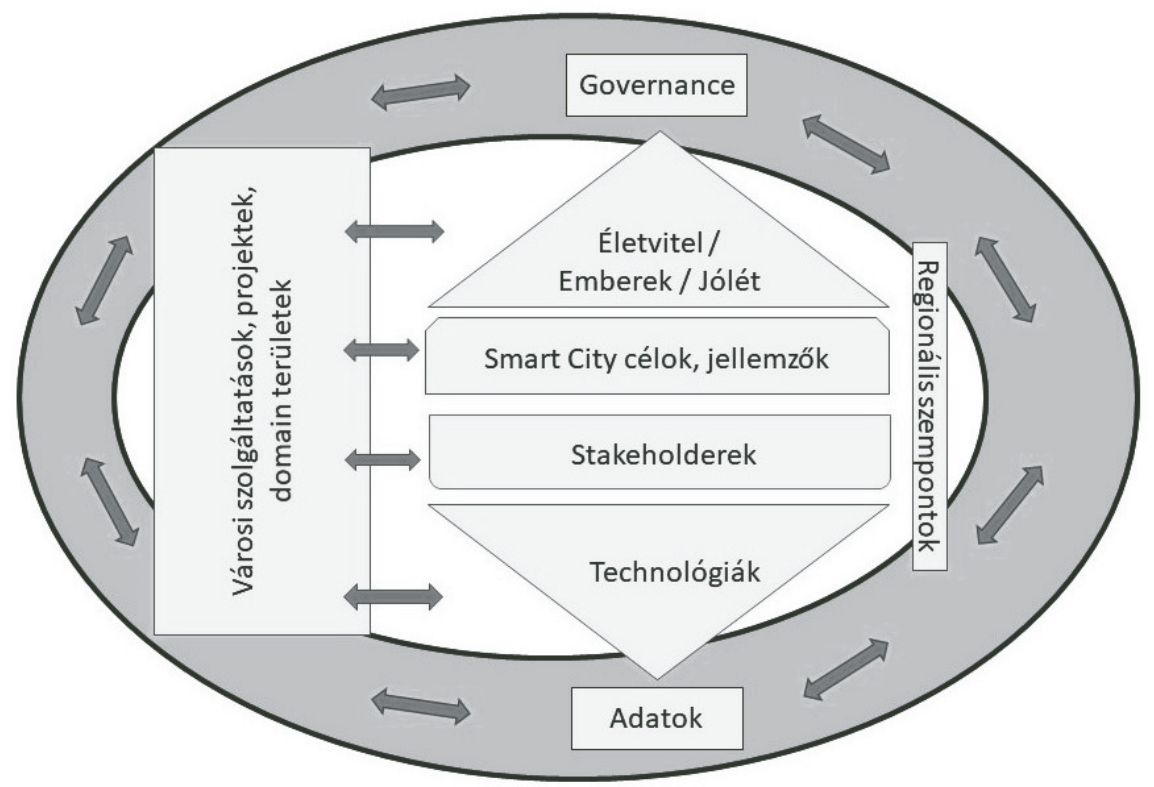

Forrás: saját szerkesztés

holderek számára egyaránt könnyedén értelmezhető, esetleg zsinórmértékként alkalmazható legyen.

Fontos eleme a modellnek, hogy az okos város működtetéséhez szükség van egy keretrendszerre, vagyis egy (informatikai és irányítási) „platformra”, amely minél nagyobb lefedettséggel képes kezelni a szakterületek, a rendszerek, a feladatok, a strukturált és strukturálatlan adatok körét, amely minél több külső fél, piaci szereplő, érdekelt csatlakozását lehetővé teszi. Ez a platform egyfajta kollaborációs felület, akár a kemény (valódi, a rendszereket összekapcsolni képes informatikai platformrendszer értelemben), akár a puha (elvi, irányítási keret, kormányzás) értelmezésben. Logikai helyüket illetően itt található az okos város ökoszisztéma dinamikájáért felelős, a tanulmányunk szempontjából kiemelt fontosságú két tényező: az „adatok” és a „governance”. Ez a két elem köti össze a többi modelltényezőt a platform mint koncepcionális együttmüködési felület jóvoltából. A „platformot" a modellben az ellipszissel jelölt kapcsolati síkidom jelképezi.

Az ,adatok” tényező teszi kézzelfoghatóvá az elméleti összefüggéseket. Az adatalapú működés, az adatalapú döntéshozatal, az adatok által befolyásolt (adott esetben automatikus, algoritmizált) városirányítás kemény bázisát biztosítja. Az adat áramlik a modell többi tényezője között. Az áramlásnak a „platform” mint informatikai rendszer ad teret. 
A „governance” a célok megvalósításának kormányzási módszertanaként jelenik meg a modellben, azon a módon, ahogy arról az elméleti fejezetekben írtunk. A „governance” tényező ugyancsak átitatja a rendszer egészét. A közös megértés, a hasonló mechanizmusok, az azonos elvek, az egyetértésben meghatározott célok, a közös cselekvés letéteményese. A kormányzás tényezője is a „platform” része. A „platform” vezetési absztrakcióként, de akár irányító informatikai rendszerként is megjelenhet ebben a nézetben.

Az adatokra épül a ,technológia” tényezo, amely a mért értékeket gyüjteni, feladni, feldolgozni, aggregálni, bemutatni, riportozni, visszacsatolni képes a rendszerek, szakterületek, szolgáltatások, stakeholderek között megosztva. A „technológia” halmazba tartoznak az alkalmazások, az adatkapcsolatok, az intelligens mérők és valamennyi informatikai rendszerelem.

A ,stakeholderek” csoportjába gyüjtöttük azokat a résztvevőket, akiknek bevonásával az okos város életre kel. Köztük a lakosság, a vállalkozói és civil szféra, az egyetemi, kutatás-fejlesztési kapcsolatok egyaránt megjelennek. Egyidejűleg vesznek részt a célok kijelölésében és azok megvalósításában, illetve a létrejött eredmények hasznosságainak kiaknázásában.

Az „okos város operatív célok, jellemzők” halmaz azokat a kifejezéseket, ideákat, célokat gyüjti csokorba, amelyek alkalmazásával megkülönböztetjük a XXI. század digitális okos városát (okos város törekvéseit) a korábbi korszak városaitól, törekvéseitől. Ez az innováció, az intelligencia, a hatékonyság rétege. Ezek a célok kézzelfoghatóak. Hozzájuk kapcsolódnak a projektek a város megannyi területéről.

A célok és a jellemzők fölött pedig megjelenik az ember; az okosváros-gondolat stratégiai, központi elemeként. Ez az „életvitel, emberek, jólét” szférája. Az okos városhoz kapcsolódó azon eszméket, ideákat soroltuk ebbe a halmazba, amelyek az élhetőség, életminőség, társadalmi kapcsolatok, és az ember (lakosság, városi polgár) nézőpontjából mutatnak irányt és jelölnek ki stratégiai célokat.

A „városi szolgáltatások, projektek, domain területek” halmazra mint a város legfontosabb müködési egységére tekintünk. Az energia, a közlekedés, a vízgazdálkodás mellett a környezet kezelésével kapcsolatos törekvéseket is ebbe a kategóriába soroltuk. Az okos város szempontjából ezek a városi domain/ágazati területek nyilvánvalóan nagyon fontosak, sőt, a legtöbb esetben az okos város megvalósításának fókuszában állnak úgy stratégiai, mint operatív tekintetben. A mi modellünkben a „városi szolgáltatások, projektek, domain területek” egyfajta tartóoszlopként kerültek vizualizálásra. Az okosváros-koncepció áthatja ezeket a területeket, de meglátásunk szerint meg is haladja azokat.

A modellben szerepet kap a regionalitás. Az okos város megoldásai ugyanis túlmutathatnak a város földrajzi és adminisztratív határain, mivel a város ellátási-szolgáltatási és foglalkoztatási szempontból szimbiózisban él vonzáskörzetével. Az okos városban alkalmazott technológiák pedig megszólítják a város határain túl élőket, az agglomeráció népességét is. Az okos régió, az okos városhálózat 
megvalósulása a digitális integráció logikus és szükséges (noha idealista) következő szintje (Harris 2017). Kijelenthetjük, hogy az okos régió kialakítása során a területi, társadalmi, gazdasági kohézió létrehozására irányuló beavatkozások szempontjából nem feltétlenül szükséges az adminisztratív, közigazgatási határokhoz igazodni. Célszerủ a beavatkozásokhoz az alkalmas szintet, illetve a megfelelő funkcionális téregységet megtalálni (Somlyódyné Pfeil 2019). Az együttműködés lehetséges területei közül kiemelkedik az energetika és a közlekedés, de számos példát találtunk a turizmusra épülő közös gondolkozásra, adott esetben regionális applikáció-fejlesztésre is. A hagyományos korlátok lebontása, a közös tervezés, a decentralizáció, a szerepek felvállalása, a kapcsolatok kiaknázása lehetővé teszi a magasabb területi szint, az okos régió kialakítását (Calzada 2017).

A regionális szempont megjelenítésével a modellben felsejlik egy újabb értelmezés lehetősége, amelyben a mikro- (okos ágazati és közszolgáltató vállalatok), a mezo- (okos város) és a makro- (okos régió) dimenziók önállóan is, a jelen tanulmány okosváros-központú megközelítésétől eltérő módon is elemezhetővé válnak.

\section{A modell reprezentációja az elemzett városok esetében}

Érdekesnek találtuk a modell belső arányait az öt szóban forgó város esetében a modell igazolása gyanánt is vizualizálni. A 5. ábra azt mutatja, hogy a vizsgált stratégiai dokumentumok a szemantikai elemzést követően magukban foglaljáke megalkotott elméleti halmazainkat, illetve, hogy vannak-e jelentősen felül-, vagy alulreprezentált halmazok egymáshoz képest, esetleg a városok összességére jellemző számtani átlaghoz képest.

Az öt stratégiai dokumentum közvetlen összehasonlítása helyett módszertani kiigazítást hajtottunk végre annak érdekében, hogy az eltéréseket egyszerű matematikai alapon kisimítsuk. A keresett kifejezések és az ezekből épített halmazok megjelenését egy oldalra vetítettük - kiszürve az oldalszámok jelentős különbségeit -, majd az így kapott egy oldalra vetített találatokat arányosítottuk egymással. Így jöttek létre az 5. ábra százalékos értékei. Az ábrán látható ábramagyarázó számértékek oszloponként alulról rétegződnek egymásra 1-től 8-ig.

Megállapíthatjuk, hogy a tanulmány hipotézise igazolást nyert, miszerint az elvégzett halmazalkotást követően a vizsgált stratégiai dokumentumokban éppúgy megtalálhatóak az elméleti, mint a pragmatikus szempontú szakirodalmi tanulmányok hívószavai.

Mind az öt vizsgált dokumentumban találhatunk továbbá megfelelő szemantikai utalásokat, úgy a „governance”, mint az „adat” fontosságát illetően. A kormányzás megjelenése releváns 9-19 százalékos reprezentációval bír a modellhalmazok egymás közötti viszonyrendszerében, ami azonban az e-kormányzás tényleges működéséről keveset árul el. Több magyar nagyváros okossá válását nehezíti ugyanis az érintett lakosság, a civil szféra részvételének és kezdeménye- 
5. ábra: A modell reprezentációja az elemzett városok esetében The representation of the model by the analyzed cities

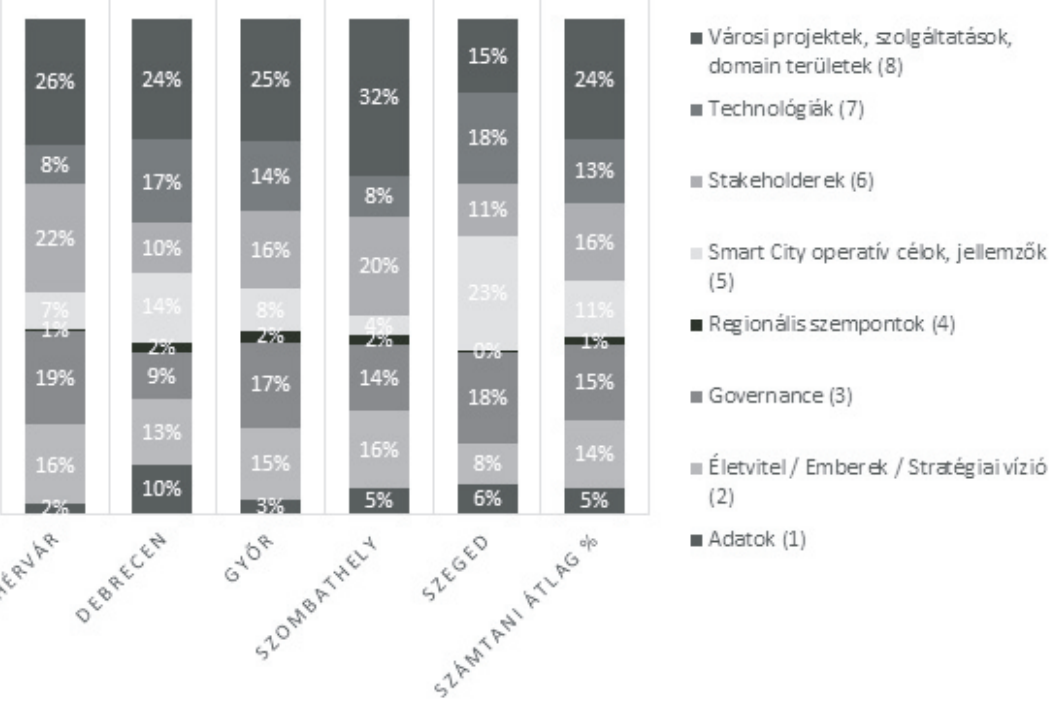

Forrás: saját szerkesztés

zéseinek gyengesége, illetve az, hogy a vonatkozó stratégiai célok gyakorlatba való átültetésében feloldhatatlan korlátot jelent a városvezetés és a helyi társadalom együttműködési mechanizmusainak hiánya (Varró, Szalai 2021).

Ugyanakkor az adat (adatkezelés, adatgyüjtés, adatalapú döntés) sokkal kevésbé jelenik meg a dokumentumokban. Megítélésünk szerint fontosságához képest alulsúlyozottan, 2-10 százalékban. Mindez azért aggasztó, mert az okosváros-vezetés és -irányítás legfontosabb menedzsment alterületéről van szó. Mint azt korábban jeleztük, az adatszervezés, az adatfeldolgozás, az adatok gyüjtése és rétegzése jelenti az okos város újfaja operatív vezetésének alapját. A legkevesebb adatra vonatkozó találatot Székesfehérvár és Győr dokumentumaiban találunk (2\%, illetve 3\%). Szeged és Szombathely átlagos értéket képvisel, míg Debrecen 10 százalékkal kimagaslik az elemzett városok közül. Egy mondat erejéig kilépve a modell elemi tényezőinek és azok reprezentáltságának ismertetéséből, modellünk absztrakt, dinamizáló, kollaborációs rétege, az (informatikai és irányítási) „platform” is megjelenik a dokumentumokban. Igaz, önmagában jelentősen alulreprezentált módon. (A platform kifejezés a „technológia” szóhalmaz része.)

A dokumentumok technológiai érzékenysége - technológia halmaz - jelentősen szór, 8\% Győr, 18-18\% Szombathely és Szeged esetében. Erre magyarázatot adhat, hogy a vizsgált stratégiák közül az elemzett győri dokumentum készült legrégebben, illetve jellegéből fakadóan (településfejlesztési stratégia) kevésbé okosváros-fókuszú, mint Szegedé (Smart City koncepció). 
A stratégiai célok (életvitel/emberek/jólét) és az okos város operatív célok (Smart City célok, jellemzők) viszont kiegyensúlyozottan, egymást kiegészítve jelennek meg valamennyi dokumentumban, kis szórás mellett, együttesen, átlagosan 24 százalékos arányban. Ebből az előbbi halmaz (stratégiai célok) valamennyi tervdokumentumban szignifikánsan megjelenik 8-16 százalékos szórással.

Debrecen Smart City Stratégiája a leginkább technológiafókuszú, igaz, ez a legfrissebb, 2020-as keltezésű okos város stratégiai dokumentum. Érdekességként említjük, hogy a debreceni stratégiában a közlekedés erős hangsúllyal jelenik meg.

A vizsgált dokumentumok közül a győri és a szombathelyi stratégia a legkevésbé okosváros-fókuszú. Ez a Smart City operatív célok, jellemzők alacsony reprezentáltságából (2\%; 4\%), illetve a dokumentumok jellegéből következik. Mindkettő településfejlesztési, nem kifejezetten Smart City stratégia. Míg a székesfehérvári stratégia kidolgozott módon ismerteti a megvalósítandó projekteket, addig a szegedi okosváros-stratégia nyelvezete a legfrissebb, legmodernebb, leginkább előremutató.

A regionalitás (regionális szempontok), azaz a területi szemlélet ugyanakkor szinte egyáltalán nincs jelen a dokumentumokban. A városon túlmutató együttműködés gondolata hiányzik a hazai okosváros-stratégiákból. A „regionális” kifejezés ugyan megtalálható bennük, ám csupán az adott város regionális feladataira vonatkozó hivatkozásként. Olyan, mintha az okos város lenne a logikai aggregáció, az integráció csúcsa, ami megítélésünk szerint nem felel meg a valóságnak.

Érdekes tanulság, hogy az összehasonlításban jól észlelhető az időtényező hatása. Noha a vizsgált dokumentumok szignálásának időpontjai között nem telt el öt év, mégis észlelhető az okosváros-jelenség és a hozzá kapcsolható kifejezések, terminusok előretörése a dokumentumok megszületésének időrendjében. Hasonlóképp érzékelhető, hogy az okosváros-víziót az integrált településfejlesztési stratégia részeként bemutató városok dokumentumaihoz képest az önálló okosváros-stratégiákban előtérbe kerül a technológia, a szoftveres megoldások igénye és a rendszerszemlélet.

Lényeges szemantikai összefüggésre vetül fény, amikor a keresett szavak, kifejezések - halmazoktól független - önálló megjelenéseit vizsgáljuk. Sok olyan fontos szó, kifejezés alig található meg a tervdokumentumokban, amelyeket dominánsnak vélnénk az okosváros-modellek alapján. Néhány elméleti terminus technicus teljességgel hiányzik. Köztük olyanok is, mint az IoT, a platform, governance, KPI, közösségi média kifejezések. Ez ugyan elgondolkoztató, sőt adott esetben megdöbbentő lehet, de a hiányuk ellenére sem jelenthetjük ki, hogy az elemzett stratégiai dokumentumokban nem jelenik meg az e fogalmakhoz kapcsolódó gondolatiság. Ha a konkrét szavak nem is szerepelnek, az általunk épített modell kategóriái mindenhol beazonosíthatóak; más szavakkal, más kifejezésekkel, talán kevésbé szakmaian, kevésbé specifikusan, estenként szinonimaként.

Fontos azonban megemlítenünk azt is, hogy a „városi projektek, szolgáltatások, domain területek" halmaz kifejezései szerepelnek a leggyakrabban az önálló megjelenések között (15-32\%) (energia, közlekedés, vízgazdálkodás). Ez is meg- 
erősíti egyfelől e halmaz pozícióját a modellben, másfelől lényeges szerepét az okosváros-koncepció gyakorlati megvalósításában, valamint a stratégiai dokumentumok erős projektfókuszát. Végül a legkevésbé és a leginkább alkalmazott szakkifejezések közül néhány példát a 2. táblázat mutat be.

2. táblázat: Leggyakrabban és legritkábban megtalált kifejezések köre

The list of expressions that were found most often / less often by the research

\begin{tabular}{lcc}
\multicolumn{1}{c}{ Kitejezés } & Kategória & Szum \\
\hline Közlekedés & Városi projektek, szolgáltatások, domain területek & 777 \\
Környezet & Városi projektek, szolgáltatások, domain területek & 774 \\
Gazdaság & Stakeholderek & 754 \\
Gapcsolat/kapcsolódó & Governance & 736 \\
Energia & Városi projektek, szolgáltatások, domain területek & 733 \\
Smart & Smart City célok, jellemzők & 582 \\
Víz & Városi projektek, szolgáltatások, domain területek & 566 \\
Adat/adatbázis & Adat & 522 \\
Integrált / integráció & Technológia & 492 \\
... listatörés ... & ... listatörés ... &... listatörés .. \\
Életvitel & Életvitel / Emberek & 9 \\
IOT & Adat & 4 \\
Közösségi média & Technológia & 4 \\
Leadership & Governance & 2 \\
Governance & Governance & 1 \\
Regionális együttmüködés & Regionális szempont & 1 \\
KPI & Adat & 0 \\
E-governance & Governance & 0 \\
Okos régió & Regionális szempont & 0 \\
\hline
\end{tabular}

Forrás: saját szerkesztés

Magyarázat: A listatörés esetében nem a teljes lista látszik, hanem csak az eleje és a vége, tehát a szélső értékek.

\section{Összefoglalás}

Felfogásunk szerint az okos város a kapcsolódásokat, az együttműködést, az értékteremtést és az embert állítja középpontba. Megvalósítása során a szakmai területek közötti határokat (mért) adatalapon elhomályosítani képes mestertervről beszélünk, amely a városra holisztikus nézőpontból, egységként tekint és felruházza azt új, egyedi, okos vízióval (Effing 2017). Nincs egy általános érvényü sikerrecept vagy formula az okos várossá válás levezénylésére. Az okos várossá válást mint komplex folyamatot helyi kontextusba kell helyezni (Starr, Smith 2018).

Meglátásunk szerint az átalakulás folyamatát, illetve az okos várost magát az e-kormányzási (e-governance) módszertan alkalmazásával, erős bevonó attitűd 
mellett lehet hatékonyan menedzselni. Az okos város innovatív, turbulens, komplex rendszerét innovatív irányítási rendszerek tudják a polgárok digitális igényeinek megfelelően kiaknázni. Az okosváros-kormányzásra összességében a governance fó elemeinek technológiával átitatott evolúciójaként tekinthetünk, amely társadalmilag felelősségteljes és együttműködő rendszert eredményez (Patapas et al. 2014).

Az okos város irányításának másik kulcstényezője a mért adat és a feldolgozott, rendszerezett adatokból származó új információs réteg, a rendszerek összekapcsolásának lehetősége, illetve a kapcsolatok alapján megvalósuló hatékony és sok esetben automatikus döntések köre (Bloem et al. 2014). Úgy véljük, hogy az e-governance és az adat az okosváros-paradigma kitüntetett elemei. Ugyanis az okos város társadalmi szempontból nyitott volta és a mért adatokra épített digitális dimenziója erősíti, támogatja a város fejlődését, új szolgáltatásokat, új minőséget hozva létre.

Fontosnak tartjuk, hogy az okosváros-stratégia arányosan keresse az egyensúlyt az elmélet és a technológia, a jövőkép és az operatív menedzsment között, illetve, hogy a közösség bevonásával egyre nagyobb teret nyisson a közösségi létrehozás (co-creation) számára, előmozdítva az Okos város 3.0 elveinek megvalósulását. Mindennek igazolására öt magyarországi nagyváros stratégiai dokumentumát elemeztük szemantikai vizsgálattal, illetve készítettük el ezzel párhuzamosan a Szinergikus okos város modellünket - az egyensúly és a dinamikusság modelljét.

A modellünk szerint a kollaborációt támogató (informatikai és irányítási) „platform”, az „adat” és a „governance” tényezőket kiaknázva tartja mozgásban az okos várost, összekapcsolva a többi okosváros-tényezőt, hivatkozott modellelemet (4.ábra).

A vizsgált stratégiai dokumentumok szókészletét illetően igazoltuk, hogy bár eltérő arányban, de valójában lefedik az okos város megvalósításához elengedhetetlen és a modellünkben rendszerezett absztrakciós halmazokat. Megállapítottuk, hogy a nagyon hasonló szókészlet ellenére mind az öt stratégiai dokumentum és így mind az öt város másként viszonyul az okosváros-paradigmához. További elemzéssel lesznek meghatározhatók azok az okosváros-területek, amelyekre az egyes városokban kevés energia jut, vagy azok, amelyek az adott település egyedi okos város jövőképének és projektjeinek központi gondolatát alkotják.

\section{Jegyzetek}

1 Példák az okos város koncepció által lefedett szakmai területekre: adminisztráció, képzés, városvezetés, egészségügy, közbiztonság, ingatlanvagyon kezelése, közlekedés, hagyományos és telekommunikációs infrastruktúra, közművek (energia), környezet, gazdaság, életvitel. Minden területhez jár az okos előtag. 
2 A hackathon egy „versenyműfaj”, amelynek célja, hogy a résztvevők rövid időn belül meghatározott témában az ötlettől a megvalósításig egy informatikai megoldásokon alapuló müködő terméket építsenek fel. Azaz innovatív megoldások keresésére irányul.

3 A fogyasztói igények minél pontosabb kielégítése érdekében a vállalatok a termék fejlesztésének korai fázisába bevonják a fogyasztót, felhasználót, aki aktív módon részt vesz a közös értékteremtési folyamatban.

4 Játékelemek alkalmazása az élet játékon kívüli területein, például az üzleti szférában.

\section{Irodalom}

Achaerandio, R., Bigliani, R., Curto J., Gallotti, G. (2012): Smart Cities Analysis in Spain 2012 -The Smart Journey. IDC España, https://www.idc.com (Letöltés: 2018. 12. 09.)

Albino, V., Berardi, U., Dangelico R. M. (2015): Smart Cities: Definitions, Dimensions, Performance, and Initiatives. Journal of Urban Technology, 1., 3-21. https://doi.org/10.1080/10630732.2014.942092

Allam Z., Newman, P. (2018): Redefining the Smart City: Culture, Metabolism and Governance. Curtin University Sustainability Policy Institute (CUSP), Perth, WA 6845, Australia

Andrews, R.. Entwistle, T. (2014): Public service efficiency: Reframing the debate. Routledge, London and New York

Angelakoglou K., Nikolopoulos, N., Giourka, P., Svensson, I-L., Tsarchopoulos, P. Tryferidis, A., Tzovaras, D. (2019): A Methodological Framework for the Selection of Key Performance Indicators to Assess Smart City Solutions. Smart Cities, 2., 269-306. https://doi:10.3390/smartcities2020018 www.mdpi.com/journal/smartcities

Bakonyi P. (2018): Az okos város fejlesztési terve. In: Sallai Gy. (szerk.): Az okos város (Smart City). Dialóg Campus Kiadó, Budapest, 49-64.

Balogh Zs. Gy., Budai B. B. (2018): E-önkormányzat. Nordex Nonprofit Kft., Dialóg Campus Kiadó, Budapest

Bélissent, J., Mines, C., Radcliffe, E., Darashkevich, Y. (2010): Getting Clever About Smart Cities: New Opportunities Require New Business Models. Forrester Research, Inc. 1-33. https://www.forrester.com (Letöltés: 2018. 12. 08.)

Benz, A. (2004) (Hrsg.) Governance - Regieren in komplexen Regelsystemen. Eine Einführung. VS Verlag für Sozialwissenschaften, Wiesbanden

Berthon, B. (2011): Building and Managing Intelligent City. Accenture https://www.accenture.com (Letöltés: 2019. 10. 20.)

Bloching, B., Leutiger, P., Oltmanns, T., Rossbach, C., Schlick, T. (2015): The Digital Transformation of Industry. Roland Berger Strategy Consultants $\mathrm{GmbH}, 1-52$. https://www.rolandberger.com (Letöltés: 2017. 12.31.)

Bloem, J., van Doorn, M., Duivestein, S., Excoffier, D., Maas, R., van Ommeren, E. (2014): The Fourth Industrial Revolution. Sogeti VINT, LINE UP boek en media bv, Groningen (Letöltés: 2019. 08.19.)

Bueti, C. (2017): Collection Methodology for Key Performance Indicators for Smart Sustainable Cities; U4SSC Initieative. ITU - International Telecommunication Union, Switzerland https://www.itu.int/ en/ITU-T/ssc/united/Pages/default.aspx (Letöltés: 2020. 03.16.)

Calzada, I. (2017): Problematizing and Politicizing Smart City-Regions: Is Devolution Smart? In the Special Issue 'From Smart City to Smart Region. Meanings, Governance, Policies and Projects'. Territorio, 83., 37-47. DOI: 10.3280/TR2017-083005.

Carr, L., Linton, G., Jeavons, P. (2011): Oracle's Solutions for Smart Cities: Delivering 21st Century Services. Oracle Whitepaper, Oracle Corporation, https://www.oracle.com (Letöltés 2020. 01. 25.)

Cassandras, G. C. (2016): Smart Cities as Cyber-Physical Social Systems, Engineering, 2., 156-158. https://doi.org/10.1016/J.ENG.2016.02.012 
Csányi E. (2020): Gazdasági frazeologizmusok szemantikai elemzése. In: Besznyák R. (szerk.): Porta Lingua - 2020. Szaknyelvoktatás és -kutatás nemzetközi kontextusban. SZOKOE Szaknyelvoktatók és -Kutatók Országos Egyesülete, Budapest, 93-102. https://doi.org/10.48040/PL.2020

van Dijk, A., Teuben, H. (2015): Smart Cities - How rapid advances in technology are reshaping our economy and society. Deloitte The Netherlands, November https://www2.deloitte.com/content/dam/ Deloitte/tr/Documents/public-sector/deloitte-nl-ps-smart-cities-report.pdf (Letöltés: 2018. 12.09.)

Dobor K., Kulcsár S., Nagy P., Sík A., Szemerey S., Vasvárné Menyhárt É. (2015): Smart City tudásplatform, Lechner Nonprofit Kft., Budapest

Effing, R. (2017): Whitepaper Smart City Strategy: Creating a bridge between smart city technology and strategic city planning. Axion University of Applied Sciences/ University of Twente, 1-6. www.smartcitystrategy.eu (Letöltés: 2018. 12.08.)

Fang, Z. (2002): E-Government in Digital Era: Concept, Practice, and Development. International Journal of The Computer, The Internet and Management, 2., 1-22.

Giffinger, R., Pichler-Milanovic, N., Fertner, C., Kramar, H., Kalasek, R., Meijers, E. (2007): Smart Cities: Ranking of European Medium-sized cities, Centre of Regional Science (SRF), Vienna University of Technology, Vienna

Hanák P. (2018): Okos életvitel. In: Sallai Gy. (szerk.): Az okos város (Smart City), Dialóg Campus Kiadó, Budapest, 153-185.

Hara, M., Nagao, T., Hannoe, S., Nakamura, J. (2016): New Key Performance Indicators for a Smart Sustainable City. Sustainability, 8., 206. https://doi:10.3390/su8030206, www.mdpi.com/journal/sustainability

Harris, J. (2017): Better Planning: Smart City-Regions, Position paper (September 2017) https:// www.rtpi.org.uk/betterplanning (Letöltés: 2020. 01. 25.)

IMD (2020): Smart City Index. IMD Word Competitiveness Centre - Centre for Innovative Cities - IMD Smart City Observatory. https://www.imd.org/smart-city-observatory/smart-city-index (Letöltés: 2020. 11. 16.)

Józsa V. (2019): A vállalati beágyazódás útjai Magyarországon. Dialóg Campus Kiadó, Budapest

Karabegović, I. (2017): Digital Technology as the key Factor in the Fourth Industrial Revolution - Industry 4.0. International Journal of Engineering and Advanced Research Technology, 3., 17-22. https:// ijeart.com/download_data/IJEART023313.pdf (Letöltés: 2018. 12. 09.)

Khan, M. S., Sulgrove, A., Silverberg, R., Loderup, L., Berst, J. (2017): GDT Smart City Solutions on Intel ${ }^{\oplus}$-based Dell EMC infrastructure DELL EMC Whitepaper https://www.dellemc.com/fr-mg/collaterals/ unauth/white-papers/smart-city-white-paper.pdf (Letöltés: 2020. 01. 25.)

Klein, M. (2020): The intelligent enterprise in the experience economy for future cities. SAP Industries White Paper https://www.sap.com/latinamerica/documents/2017/11/d4ca768e-de7c-001082c7-eda71af511fa.html (Letöltés: 2020.01.25.)

Kourtit, K., Nijkamp, P. (2017): A big data dashboard architecture for a computable intelligent city, BDC 1., 23-34. https://doi.org/10.6092/2284-4732/5471

Kovács K. (2018): Az okos város modelljei. In: Sallai Gy. (szerk.): Az okos város (Smart City), Dialóg Campus Kiadó, Budapest, 35-48.

Lados M., Horváthné Barsi B. (2011): Smart Cities tanulmány. MTA RKK Nyugat-magyarországi Tudományos Osztály, IBM, 1-120.

Leleux, C., Webster, W. (2018): Delivering Smart Governance in a Future City: The Case of Glasgow. E-Government and Smart Cities: Theoretical Reflections and Case Studies. Media and Communication, 4., 163-174. https://doi.org/10.17645/mac.v6i4.1639

Letaifa, S. B. (2015): How to strategize smart cities: Revealing the SMART model. Journal of Business Research, 68., 1414-1419. https://doi.org/10.1016/j.jbusres.2015.01.024

Manville, C., Cochrane, G., Cave, J., Millard, J., Pederson, J. K., Thaarup, R. K., Liebe, A., Wissner, M., Massnik, R., Kotternik, B. (2014): Mapping Smart Cities in the EU. Directorate General For Internal Policies Policy Department A: Economic And Scientific Policy IP/A/ITRE/ST/2013-02, European Union https://www.europarl.europa.eu/RegData/etudes/etudes/join/2014/507480/ IPOL-ITRE_ET\%282014\%29507480_EN.pdf (Letöltés: 2020. 01. 25.) 
Mechant, P., Walravens, N. (2018): E-government and smart cities: Theoretical Reflections and Case Studies. Media and Communication, 4., 119-122. https://doi.org/ 10.17645/mac.v6i4.1848

Meijer, A., Bolivar, M. P. R. (2016): Governing the smart city: a review of the literature on smart urban governance. International Review of Administrative Sciences, 2., 392-408. https://doi.org/ 10.1177/0020852314564308

Middleton, E. (2018): Smart City Strategic Planning in North America: Learnings for London. Harvard Kennedy School of Government, 1-21. https://www.london.gov.uk/sites/default/files/smart_city_strategic_ planning_in_na_for_smart_london_em_vfinal.pdf (Letöltés: 2018.12.09.)

Nemeslaki A. (2017): Okos városok igazgatása. Magyar Jövő Internet Konferencia https://www.hte.hu/ documents/10180/4562336/HT_2018_1_MJIK2017_07_Nemeslaki.pdf (Letöltés: 2020. 08. 31.)

Nielsen, P. S., Ben Amer, S., Halsnæs, K. (2013): Definition of smart energy city and state of the art of 6Transform cities using Key Performance Indicators: Deliverable 1.2. DTU Library https://backend.orbit.dtu.dk/ws/portalfiles/portal/60555188/Definiton_of_smart_city_D1.2_FINAL.pdf (Letöltés: 2020. 01. 25.)

Osborne, S. P. (2010) (ed.): The New Public Governance. Emerging Perspectives on the Theory and Practice of Public Governance. Routledge, London and New York

Paskaleva, K., Evans, J., Martin, C., Linjordet, T., Yang D., Karvonen, A. (2017): Data governance in the sustainable smart city. Informatics, 4., 1-19. https://doi.org/10.3390/informatics 4040041

Patapas, A., Raipa, A., Smalskys, V. (2014): New Public Governance: The Tracks of Changes. International Journal of Business and Social Research, 5., 25-32. http://thejournalofbusiness.org/index.php/ site/article/view/478/415 (Letöltés: 2020. 05. 18.)

Pereira, G. V., Parycek, P., Falco, E., Kleinhans, R. (2018): Smart Governance in the Context of Smart Cities: A Literature Review. Information Polity, 2., 1-20. https://doi.org/10.3233/IP-170067

Rechnitzer J. (2016): A területi tóke a városfejlődésben - A Győr kód. Dialóg Campus, Budapest-Pécs

Sallai Gy. (2018): Az okos város koncepciója. In: Sallai Gy. (szerk.): Az okos város (Smart City). Dialóg Campus Kiadó, Budapest, 11-34.

Schwab, Ch., Boucheart, G., Kuhlmann, S. (Hrsg.) (2017): The Future of Local Government in Europe. Lessons from Research and Practice in 31 Countries. Moderninisierung des öffentlichen Sektors, Sonderband 47. Nomos, Universität Potsdam, Baden-Baden http://dx.doi.org/10.5771/9783845280639.

Somlyódyné Pfeil E. (2019): A városok szerepe a területi kormányzásban. Nemzeti Közszolgálati Egyetem, Budapest

Szalai Á. (2020): Az okosváros-koncepció kritikai földrajzi vizsgálata - elméleti háttér és lehetséges kutatási irányok. Tér és Társadalom, 2., 89-107. https://doi.org/10.17649/TET.34.2.3201

Szarek-Iwaniuk, P., Senetra, A. (2020): Access to ICT in Poland and the Co-Creation of Urban Space in the Process of Modern Social Participation in a Smart City-A Case Study. Sustainability, 12 (5), 2136 https://doi.org/10.3390/su12052136

Starr, G., Smith, A. (2018): Smart planning our future cities. Supporting healthy, equitable and sustainable communities in the Digital age. Canadian Urban Institute, Evergreen, 1-12. https://www.evergreen.ca/downloads/pdfs/2018/STARR_Fleck_Evergreen-Mid-sized\%20Cities-Series\%20 Design_WEB.pdf (Letöltés: 2020. 05. 18.)

Tuncer, F. (2017): Smart governance for smart cities. WTIS-17, 16.11.2017, Hammamet, Tunisia, 1-9. https://www.itu.int/en/ITU-D/Statistics/Documents/events/wtis2017/Plenary7_Tuncer.pdf (Letöltés: 2020. 05.18.)

Twizeyimana, J. D., Andersson, A. (2019): The public value of e-government - A literature review. Government Information Quarterly, 36., 167-178. https://doi.org/10.1016/j.giq.2019.01.001

Varró, K., Szalai, Á. (2021) Discourses and practices of the smart city in Central Eastern Europe: insights from Hungary's 'big' cities. Urban Research \& Practice https://doi.org/10.1080/175350 69.2021.1904276

Vida R. (2018): Az infokommunikációs infrastruktúra, In: Sallai Gy. (szerk.): Az okos város (Smart City). Dialóg Campus Kiadó, Budapest, 67-93.

Vincze V., Üveges I., Szabó M. K. (2021): Magyar nyelvü spontán beszéd szemantikai-pragmatikai sajátságainak elemzése nagyméretü korpusz (StaffTalk) alapján. XVII. Magyar Számítógépes Nyelvészeti Konferencia Szeged, 2021. január 28-29. 183 http://publicatio.bibl.u-szeged.hu/20683/1/Ma- 
gyarnyelvuspontanbeszedszemantikaipragmatikaisajatsagainakelemzesenagymeretukorpuszStaff Talkalapjan.pdf (Letöltés: 2021. 03. 20)

De Vries, M. S. (2002): Can you afford honesty? A comparative Analysis of Ethos and Ethics in local government. Administration and Society, 3., 309-334. https://doi.org/10.1177/009539902400387218

Woetzel, J., Remes, J., Boland, B., Lv, K., Sinha, S., Strube, G., Means, J., Law, J., Cadena, A., von der Tann, V. (2018): Smart Cities: Digital solutions for a more liveable future. McKinsey Global Institute https://www.mckinsey.com/business-functions/operations/our-insights/smart-cities-digital-solutions-for-a-more-livable-future\# (Letöltés: 2021. 06. 01.)

Zygiaris, S. (2012) Smart city reference model: Assisting planners to conceptualize the building of smart city innovation ecosystems. Journal of the Knowledge Economy, 4., 217-231. https:// doi.org/10.1007/s13132-012-0089-4

\section{Egyéb források}

http://www.smart-cities.eu/download/smart_cities_final_report.pdf (Letöltés: 2018. 12.09.)

http://www.smartcitywien.at (Letöltés: 2018. 12.09.)

https://www.edmonton.ca/city_government/documents/PDF/Smart_City_Strategy.pdf (Letöltés: 2018. 12. 09.)

https://www.unescap.org/sites/default/files/good-governance.pdf (Letöltés: 2018. 12. 31.) http://unpan1.un.org/intradoc/groups/public/documents/nispacee/unpan006804.pdf (Letöltés: 2020. 04. 05.) https://www.szekesfehervar.hu/_upload/editor/2018/Onkormanyzat/dukumentumok/hirdetmeny_rendelet_felhivas_tajekoztato/03_SZEKESFEHERVAR_ITS_2018_08_02_tars_egyezt_verzio.pdf (Letöltés: 2020.04. 05.)

http://smartcity.debrecen.hu/docs/Debrecen\%20Smart\%20City\%20Strategia.pdf (Letöltés: 2020. 04. 05.) https://gyor.hu/easy-docs/5dc982a2e14e2 (Letöltés: 2020. 04. 05.)

https://www.szombathely.hu/onkormanyzat/koncepciok-tervek/telepulesfejlesztes/ (Letöltés: 2020. 04. 05. https://www.szegedvaros.hu/letoltheto-csatolmany/?ID=20557 (Letöltés: 2020. 04. 05.)

https://publicadministration.un.org/egovkb/Portals/egovkb/Documents/un/2018-Survey/E-Govern ment\%20Survey\%202018_FINAL\%20for\%20web.pdf (Letöltés: 2020. 08. 26.)

https://www.oecd-ilibrary.org/governance/european-principles-for-public-administration_5kml60zw dr7h-en / Sigma Papers (Letöltés: 2020. 08. 26.) 